\title{
THE RELATIONSHIP BETWEEN PRINCIPAL LEADERSHIP AND SCHOOL CLIMATE AND TEACHERS' JOB SATISFACTION OF THE SPK SECONDARY SCHOOL IN PAMULANG, TANGERANG SELATAN
}

\author{
Sisilia Juni Arianti \\ sisiliajuni@yahoo.com \\ Hotner Tampubolon \\ hotnertampubolon@yahoo.com \\ Tarsicius Sunaryo \\ tarsiciussunaryo@yahoo.com
}

\begin{abstract}
Job satisfaction is an important issue when dealing with the teachers' turn over in institution. Many factors influence teachers' job satisfaction, among others are the principal leadership and the school climate. This research aimed to know the relationship between those factors. This research is a correlation study. The sample is the teachers in SPK Secondary School in Pamulang, Tangerang Selatan. Questionnaires were distributed to 32 respondents. It was found out that 1.) There was a very strong, positive and significant correlation between the teacher's job satisfaction and the principal leadership, with the computed $r=.890$., 2.) There was a strong, positive and significant correlation between the teacher's job satisfaction and the school climate, with the computed $r=.795$., and 3.) There was a very strong, positive and significant correlation between the principal leadership and the school climate to the teacher's job satisfaction, with the computed $r=.905$. The findings showed that opportunity to develop, relationship between leaders and teachers, and sense of responsibility are the indicators that are very prominent in each variable. The conclusions are 1). The higher the principal leadership is, the higher the teachers' job satisfaction will be., 2). The higher the school climate is, the higher the teachers' job satisfaction will be., 3). The higher the principals leadership and the school climate are, the higher the teachers' job satisfatiction will be. Providing adequate support facilities, training, and creating a more relax atmosphere are some recommendations for maintaining the teachers' job satisfaction in that school
\end{abstract}

Keywords: Job Satisfaction, Leadership, School Climate 


\section{A. INTRODUCTION}

Teachers are the cutting edge of education. As we know, the roles of teachers are very important because they hold a major role in education. Teachers determine the success of learners, particularly those that are related to the teaching-learning process and result. Knowing the importance of teachers' roles to create good teaching-learning process and result, the need to have high qualified teachers is very important so that they can make a contribution to the world of education. Without professional and qualified ones, then educational objectives will not be achieved.

The need for qualified teachers is also seen as an important issue by SPK (Satuan Pendidikan Kerjasama) schools. The tight competition among SPK schools, makes existing teachers and prospective teachers must have good performance so that they can survive in desirable working places. Accordingly, job satisfaction of the teachers must be well maintained so that they can always work well in carrying out their duties and responsibilities with full dedication.

The same problem also was experienced by one SPK Secondary School in Pamulang, Tangerang Selatan. Since it was established, the need to have qualified teachers is always be the priority to improve the school quality. Unfortunately, some qualified teachers usually are easily moved from one school to other schools, just when their job satisfaction dropped. When the offering from other schools exists, especially with good packages, without any doubt they will quit. If they feel disappointed with the work situation, they will open the job search engine in their gadget and start to find the job vacancy. This turning over makes the school keep on thinking on how to maintain the qualified teachers.

There are a lot of factors to consider when maintaining the teachers' job satisfaction. One of them is the principal leadership. Principals are the ones who play an important role in operational activities of a school, especially for learning and teaching. Furthermore, they have direct responsibility for the implementation of all activity programs, including policies, rules and discipline. The first four years, this school has been led by 3 principals with different characters. It means that almost every year, the school has the new principal. During that time, the teachers turned over was very high due to the principal leadership.

The way principals interact with teachers and students, both as leaders who can provide guidance and example, and as leaders who are able to leverage existing resources, can affect the quality of teachers and students. They have leadership styles based on their personal abilities, and are also able to encourage other teachers and students to do something based on the vision and mission of institution. In other words, they must be accepted by those who are led because of their special skills that are appropriate for the school climate.

Creating a conductive school climate also has an impact on the teachers' job satisfaction. A positive climate will usually make the teachers better able to contribute more for the sake of a common interest in achieving the objectives of the school. The first four years, the climate in the school was not that conducive. Some teachers thought that the teachers structure was not 
arranged effectively. Due to the lack of human resource, several teachers had to teach subjects which were not their major. Relationship between principals and teachers were not that in harmony relationship. The appraisal was being a big issue as it determined the increment. They felt that supervision and monitoring must be reflected in their appraisal.

Job satisfaction is shown by teachers who feel pleasure after they perform certain works. Their being proud because they have done well as expected will allow them to give positive feedback for themselves in their daily work. It is in job satisfaction, there is seriousness in working, pleasure in doing and positive feedback. All of them will give certainly advantageous feelings. Eventhough the turning over of teachers are decreased step by step every year, the need to anticipate for not happening again is always seen as the good effort to maintain the quality of school.

Based on the above statements, it is necessary to conduct a field research which deals with the above problems. Therefore, this research tried to investigate whether or not there was a relationship between principal leadership, school climate and job satisfaction within a certain context of the education.

\section{B. THEORETICAL REVIEW}

\section{Teachers' Job Satisfaction}

Job satisfaction is one's perception about the job aspects. (Wirawan, 2014: 698). The perception can be in the form of feeling and attitude toward the job. Both of them can be positive or negative. If it is positive, then the job satisfaction will be high. On the contrary, if it is negative, the job satisfaction will be low. Teachers's job satisfaction is also being influenced by many aspects. Their feeling and attitude will show how satisfy they are. Teachers who feel happy because they have good salary and benefits, are being appreciated by their colleagus and superiors, get suitable professional development and promotion, will likely enjoy their work as teachers or educators, feel proud to be teachers, overcome stress at ease and have good performance, and so on.

According to Hinic, Grubor and Brulic (2016:503), job satisfaction is a construct which encompasses feelings that someone has about their job and a cognitive evaluation of it. In this case, teachers' job satisfaction is not only feeling but also about cognitive evaluation, in terms of productivity, absenteeism and involvement. When teachers feel satisfied with their jobs, usually their performance is high. They are willing to work extra miles, show enthusiasm when doing their responsibility. The feeling to always get involved and participated actively to the development of both individual and institution will increase their motivation to work beyond normal expectation. As a result, their job satisfaction will increase.

Job satisfaction and dissatisfaction are caused by several factors (Wirawan, 2014: 699). Those factors are: job, work condition, work environment, work secure, compensation, health coverage, pension, career, organization policy, leadership, relationship between subordinate and superior, relationship among colleagues, work autonomy and 
rewards. If teachers' perspective to the factors is positive, the teachers will feel satisfy to their job, their performance will be high and the result is the school performance will increase. On the contrary, if their perspective is negative, they will not feel satisfy to their job, finally their performance will be poor and make to the school performance low. Some reactions from the teachers who feel dissatified will be quit the job, suggest improvements, less loyal, ignore the duties, and confront ideas According to Sirota, Mischkind and Meltzer (2005: 6), satisfied workers are motivated by the following things:

1. Equity - Being treated justly in relation to the basic conditions of employment with respect to others in the organization as well as minimum personal/societal standards. Workers get fair treatment among others in the job security, compensation and respect, will be satisfied with their work.

2. Achievement - To take pride in one's accomplishments by doing things that matter and doing them well, to receive recognition for one's accomplishments, and to take pride in the organization's accomplishments. Workers who get the opportunity to do maximum work achievement, such as: getting a promotion opportunity, feels that their expertise is needed, will certainly be satisfied with the work.

3. Camaraderie - Having warm, interesting, and cooperative relations with others in the workplace; achieving a sense of community, belonging, and collegiality. The close friendship between employees with colleagues and superiors, and cooperation among them, will support the job satisfaction.

Job satisfaction depends on factors that affected it. According to Robbins (1996:192), there are 5 things that affect job satisfaction:

\section{Mentally Challenging Work}

Employees tend to like the job which gives them the opportunity to use their skills and abilities and offer duty, freedom and feedback about how well they are working on. These characteristics make the work is mentally challenged. Less challenging jobs create boredom, but too many challenging and frustrating ones, create frustation. Most employees experience pleasure and satisfaction on the conditions of the adequate challenge.

\section{Equitable Reward}

The employees want a system of wage and promotion policies which are fair, without double standards and in line with their hope. When wages are seen as fair, based on work guidance and level of skill, wage standards, then all of them will most likely generate satisfaction. Not everyone is chasing money. Many people are willing to accept enough money to work in a more desirable location or in a less demanding job or have a greater extent in the work they do. But the key to link wages with satisfaction, not about the amount that is paid; it is more on the perception of fairness.

\section{Supporting Working Conditions}


Employees concern about work environment, both for the convenience as well as for facilitating their work. They prefer the physical circumstances which are not dangerous or uncomfortable, in the terms of temperature, light, noise, and other environmental factors, which are not extreme

\section{Supportive Colleagues}

For most employees, the work also fulfils the need for social interaction. Therefore, it is not surprising when having co-workers who are friendly and supportive, will increase job satisfaction. Behavior of a supervisor also determines job satisfaction. When a supervisor is friendly and can understand, offer praise for good performance, listen to the opinions of employees, and show a personal interest in them, generally, the employee's satisfaction will improve.

\section{Personality Job Fit}

In fact the persons whose personality congruent with the job, should have the right talents and abilities to meet the demands of their jobs. Thus, it would be more likely to succeed on the job. Furthermore, it is easier for them to achieve high satisfaction in their work.

Furthermore, Luthans (2008:142) stated the similar opinion about the factors that influence the job satisfaction. They are 1.) the work, itself, 2.) pay, 3.) promotion opportunities, 4.) supervisor and 5.) coworkers. This opinion is similar to Ivancevich and Konopaske's statement (2006: 109) that numerous dimensions have been associated with job satisfaction, five in particular have crucial characteristics: 1.) pay, 2.) job, 3.) promotion opportunities, 4.) supervision, and 5.) coworker.

Based on theoretical description that has been discussed above, then it can be inferred that the teacher's job satisfaction is a condition when the teachers feel satisfied regarding the work aspects that will influence their acts.

The dimensions can be in form of teachers' achievement, when they can design the program plan well, when they can go through the process as planned and when they know that the results of their work are relevant with the school target. Relationship among colleagues and principals can be in the form of having a professional relationship, such as: discussing the plan in the meeting, reporting the incidents, supervising, and so on, while having a personal relationship, for example, as partners sometimes they hang around together, have informal discussion, etc. which are considered as the success of relationship.

Appreciation or rewards can be very significant for some teachers if it is related to salary, benefits or promotion. The sense of responsibility can be related to the school duties, such as: as teachers, person-in-charge, or when the teachers have certain position in institution. If it is related to students, it will be about the responsibility to educate the students, in the form of teaching the lesson or moral values. So the students can develop both in academic and character. The opportunity to develop 
can be in the form of career path. When teachers know how to get to the next path, or when they can improve their skill by following training, seminar, and workshop as their personal developent. Finally, fairness is sometimes considered by some teachers as important factor for job satisfaction. It can be in the treatment from principals and colleagues during their office hours when they interact together. The appraisal fairness, means a lot for teachers. It is the time when they feel that they have done well and they want all their work will be reflected in their appraisal.

\section{Principal Leadership}

There are a lot of definitions of leadership. As stated by Wirawan (2014: 6-7), there are some leadership experts who give some definitions. Gardner in 1990 defines leadership as a process of persuasion by which an individual (leadership team) induces a group to pursue objectives held by the leader or shared by the leader and his followers. Yukl, Gary in 2010 stated leadership is a process of influencing others to understand and agree about what needs to be done and how to do it, and the process of facilitating individual and collective efforts to accmplish shared objectives. Lussier, Robert N and Achua, Christopher G. in 2007 said that leadership is the influencing process of leaders and followers to achieve organizational objectives through a change. Generally, most definitions of leadership imply that it is an intentional influence of a person or a group, over other people or groups, to structure the activities and relationships in a group or an organization.

Outstanding leadership has invariably emerged as a key characteristic of outstanding schools. There can no longer be doubt that those seeking quality in education must ensure its presence and that the development of potential leaders must be given high priority. (Beare, Caldwell and Millikan, 1989: 99). It implies that school leadership has a very important role to the education world. Most of good schools have good leaders.

The term of school leadership is used for the leadership in primary and secondary levels. The school leadership is a process in which the leaders influence all students and school community to create a synergy to achieve the national educational objectives. School leadership is related to the leadership in educational institutions who manages the educational service. In school, those are considered as the school leaders are principals (Wirawan, 2014: 533).

A central element in many definitions of leadership is that there is a process of influence. Cuban (1988:193) stated that leadership refers to people who bend the motivations and actions of others to achieving certain goals; it implies taking initiatives and risks. This definition shows that the process of influence is intended to lead to specific outcomes. Stoll and Fink (1996: 109) use the similar concept of 'invitational' leadership to explain how leaders operate in schools. "Leadership is about communicating invitational messages to individuals and groups with whom leaders interact in order to build and act on a shared and evolving vision of enhanced educational experiences for pupils". Principal 
leadership needs to influence the school community in order to work together and synergize to develop the school for achieving the education objectives. Good principals must be able to have the skill to influence others. Leadership is a process of influence leading to the achievement of desired purposes. Successful principals develop a vision for their schools based on personal and professional values. They articulate this vision at every opportunity and influence their staff and other stakeholders to share the vision. The philosophy, structures and activities of the school are geared towards the achievement of this shared vision A principal is seen as a prime factor in improving school effectiveness. A principal makes a difference. Effective principal improves schools and has the following functions: (1.) to create a vision, (2.) to develop organizational culture, (3.) to create synergy, (4.) to create a change, (5.) to motivate members, (6.) to empower members (7.), to represent the social system, (8.) to be the conflict manager, (9.) to empover the organization learning (Wirawan, 2014: 64-96).

Theories about a typology for leadership adapted from Leithwood, Jantzi and Steinbach (1994: 8-15), identified six models of leadership, as follows:

1. Instructional leadership - focuses on the school's core business teaching, learning, pupils' progress and achievements. Instructional leadership focuses on teaching and learning and on the behaviour of teachers in working with students. Leaders' influence is targeted at student learning via teachers. The emphasis is on the direction and impact of influence rather than the influence process itself.

2. Transformational leadership - concerned with the commitment of colleagues, leading change, improving performance. Transformational leadership describes a particular type of influence process based on increasing the commitment of followers to organisational goals. Leaders seek to engage the support of teachers for their vision for the school and to enhance their capacities to contribute to goal achievement. Its focus is on this process rather than on particular types of outcome.

3. Moral leadership - emphasises the importance of values, vision and ethical leadership. Moral leadership is based in the values and beliefs of leaders. The approach is similar to the transformational model but with a stronger values base, that may be spiritual. Moral leadership provides the school with a clear sense of purpose.

4. Participative leadership - stresses the importance of including colleagues, shared decision-making and social capital. Participative leadership is concerned primarily with the process of decisionmaking. The approach supports the notion of shared or distributed leadership and is linked to democratic values and empowerment. Participative leadership is thought to lead to improved outcomes through greater commitment to the implementation of agreed decisions.

5. Managerial leadership - focuses on the importance of defining functions, tasks and behaviours. Managerial leadership focuses on 
functions, tasks and behaviours. It also assumes that the behaviour of organisational members is largely rational and that influence is exerted through positional authority within the organisational hierarchy. It is similar to the formal model of management.

6. Post-modern leadership- believes that any situation is open to multiple interpretations. Post- modern leadership focuses on the subjective experience of leaders and teachers and on the diverse interpretations placed on events by different participants. There is no objective reality, only the multiple experiences of organisational members. This model offers few guidelines for leaders except in acknowledging the importance of the individual.

7. Interpersonal leadership- stresses the importance of collaboration and interpersonal relationships. Interpersonal leadership focuses on the relationships leaders have with teachers, students and others connected with the school. Leaders adopt a collaborative approach which may have a moral dimension. They have advanced personal skills which enable them to operate effectively with internal and external stakeholders.

8. Contingency leadership - highlights how leaders respond to the particular organisational circumstances and challenges they face and encounter over time. Contingent leadership focuses on how leaders respond to the unique organisational circumstances or problems they face. The wide variations in school contexts provide the rationale for this model. Leaders need to be able to adapt their approaches to the particular requirements of the school, and of the situation or event requiring attention Leadership is therefore about how leaders combine and blend these models, based on the situation. These leadership models, implemented in school organization, are identified as having moderate to large effects on outcomes (Robinson, 2007:12):

- establishing goals and expectations

- strategic resourcing

- planning

- co-ordinating and evaluating teaching and the curriculum

- promoting and participating in teaching learning and development

- ensuring an orderly and supportive environment.

Dimmock and Walker (2002: 72) recognise eight interrelated elements of leadership. They claim that "the eight provide a convenient and manageable way of encapsulating school leadership":

- collaboration and partnership

- motivation

- planning

- decision-making

- interpersonal communication

- conflict

- evaluation and appraisal 
- staff and professional development

Apapde's Educational Leadership Model (AELM) drawn up by the Australia Principal Association (Wirawan, 2014:535), stated that educational leaders should have a number of competencies:

1. Curriculum and pedagogical leadership - provides an optimal learning and teaching environment that responds to national and global trends and issues, is matched with current trends and constantly evaluated.

2. Organizational leadership and management - has vision and able to develop cooperatively a common purpose and future direction, is creative and inspiring in interaction with other. Ensure smooth running and achievement of common goals and purposes.

3. Cultural and wise leadership - understands and acknowledges community cultural values acts ethically, reflects on beliefs, practice and behaviour, involves compassion clarity and courage.

4. Political and community leadership - able to negotiate with systems and sectors, parents, teachers and community member on the direction and wellbeing of the school.

Based on the description of the above theories, a principal leadership is a pattern of behavior or the way of a principal in an attempt to influence, to move and to motivate members of organization, so they are willing to undertake and to achieve the mission of the organization.

The dimension of the principal leadership can be in the form of goal setting and achievement, when they have to set clear and achievable goals and when they know the strategy on how to achieve the goal. Structure of the task can be for individual performance, to develop image for the community, parents, government or for doing their jobs as principals when managing, motivating, directing, etc. The last one is the relationship with the members of organization, especially how the principals communicate with their subordinate and how they treat teachers, such as; inspiring, encouraging, working together.

\section{School Climate}

Tagiuri (1968: 11) defined that organization climate is relatively enduring quality of the internal environment of an organization that (a) is experienced by its members, (b) influence their behavior, and (c) can be describe in terms of values of its particular set of characteristics (or attributes) of the organization. Thus, there are 3 points when discussing organization climate, namely members' experience, behavior influence and sets of values. The climate will be the conditions in which the members of the organization experience the working process and that experience will direct their behaviour to achieve the goal. In this process, there will be values that are believed by them.

Organizational climate refers to a set of organizational characteristics 
which can be created from the way an organization deals with its members (Halpin and Croft,1963: 12). The relationship of the organization members is emphasized in this definition. Members of the organization will give a personality of the organization.

Discussing on the organizational climate actually is about traits or characteristics that is felt in the work environment which arise mainly because of the activities of the organization is done consciously or not, that can affect behavior. It is in this climate that was then seen as a personality as it is understood by its members.

When visiting a school for the first time, it is easier to discover how one school can be different from other schools. School climate is a general term that refers to the feel and atmosphere of a school. Just as individuals have personalities, so too do schools; a school climate may be thought of as the personality of a school.

School climate reflects the physical and psychological aspects of the school that are more susceptible to change and provide the preconditions necessary for teaching and learning to take place and also a significant factor in process about improving academic performance and school reform (Vedavathi: 2017: 25). School climate is a set of characteristics that describe about organization and distinguish it from the other characteristics that give influence to the members of organization.

Schools that have a pleasant working climate will have a significant impact on student achievement or the quality of graduates from the school. This means that teachers surely perceive the atmosphere of work with a cool atmosphere that touched emotional state of their professionalism so that devote all they have either the energy, time, competence as a teacher or educator, commitment, attention, and various efforts in implementing the learning process.

In general, organizational climate arises from routine organizational practices that are important to members, that it is defined by members' perceptions, and that influences members' attitudes and behavior. Thus, school climate is a relatively enduring character of a school that is experienced by its participants, that affects their actions, and that is based on the collective perceptions of behavior in the school.

School organization climate will have special characteristic, such as: the facilities or tools, the level of education and work competence, the work commitments, the level of welfare assurance obtained, the arrangement of tasks and decision-making systems within the organization, the perception of each member, to the formation of the behavior of every member of the organization and so forth. All of the organizational characteristics mentioned above may contribute to certain or may affect the work behavior of members of the organization in carrying out the tasks entrusted to them.

If the characteristics of the organization are at a positive quadrant point, then the organizational facilities will be available and complete, the level of education of the organization's members are relevant, the income and welfare of the organization's members are noticed or guaranteed, good and effective. 
According to Davis (2001:1), there are two essential dimensions in climate work, namely: (1) that a work environment should be able to improve creativity and innovation as well as the changes for the the employees, (2) that the organization must understand and see the importance of changes in the organisation. Ideally an organization can create a climate that is conducive for its employees, to express his ability in accordance the change so that the factors that influence the climate of the organization must be constantly analyzed.

Tang and Chiu (2002:3) stated that the working climate of an organization can be measured through 4 dimensions, namely (1) phycological, including workload, less otonomy, less self- fulfillment, and lack of self development, (2) structural, covering the environment, the climate of harmony, and the purposes of work, (3) social, including the aspects of interaction with the jobless claims, colleagues, supervisors, support and reward, (4) bureaucrats, covering the organization's policies and conflicts roles. Four dimensions above lays out that the climate of the organization can be measured and perceived by its members.

Based on the description of the above theories, the organization climate is defined as a perception of organization aspects that will influence the behaviour of the organization members when sharing the common values, norms, attitudes, toward the organization.

In the open structure organization, a school as an organization allow all teachers to communicate and discuss about the roles and responsibility for developing the school. It will be very meaningful for them if they feel that they have the same and equal chance and opportunity to fill in the position in the institution. Dynamic performance standar will direct teachers to have the same mindset about what the school expected from their performance. Accordingly, good schools must be able to show the well-designed performance standard and every year, it must be reviewed to catch up with the development of education system.

Supporting management style is one thing that is easily been recognized by the teachers when they need help. The support to teachers must be seen as something that is honest and sincere. When teachers try to accomplish their duty, sometimes they need supporting from management, in the form of appreciation or others..

Sense of responsibility for teachers usually can be seen when they do their job for teaching their students. How they prepare all plans and materials and know how to deliver the content to the students. Another sense of responsibility can be shown when the teachers have additional responsibilities for the institution for example they have another structure position, as coordinator, supervisor or group leaders. Teachers' engagement in organization can be seen as personal needs to show their existence.

When the school has an event, the committee will be set and their willingness to make the event success can seen when they have good engagement. Sometimes schools have to participate in the community program, such as, group competition among schools in certain region or working together with parents for certain projects. In these activities, it is 
easily can be recognized the one who is seriously engaged or not.

\section{METHODOLOGY}

Since the research objective is to analyse the relationship of principal leadership, school climate and teachers' job satisfaction, the model of the research will be illustrated by the following formula:

$$
\square=\square 0+\square 1 \square 1+\square 2 \square 2+\square
$$

The respondents for the research are secondary teachers of SPK Secondary School in Pamulang, Tangerang Selatan. There are 32 teachers for lower and upper secondary. All teachers will be the population of the research. The data is collected on July-August 2019 by using questionnaire via Google Form.

\section{Validity and Reliability}

To measure what is supposed to measure is the aim of validity. The validity of the data is tested per item by using the Pearson's product-

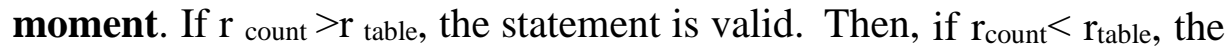
statement is not valid. With the significant $\alpha$-score 0.05 (5\%), for 32 data, the $r_{\text {table }}$ is .349 .

Reliability is related to the consistency of the instruments. The formulae used is Alpha Cronbach. The table of interpretation is as follows:

Table 1. Cronbach's Alpha Interpretation

\begin{tabular}{lc}
\hline \multicolumn{1}{c}{ Reliability } & $\begin{array}{l}\text { Reliability } \\
\text { Coefficient }\end{array}$ \\
\hline Very highly reliable & $>.90$ \\
Highly reliable & $.80-.90$ \\
Reliable & $.70-.79$ \\
Minimally reliable & $.60-.69$ \\
\hline $\begin{array}{l}\text { Unacceptable low } \\
\text { reliable }\end{array}$ & $<.60$ \\
\hline \multicolumn{2}{l}{ (Cohen, Manion, and Morrison, 2007: 506) }
\end{tabular}

Based on the table, if the variable has reliability $>.60$, the reliability can be accepted. On the contrary, if it is $<.60$, the reliability is low and can not be accepted.

\section{Descriptive Statistics}

\section{a. The distribution}

The central tendency of a distribution is an estimate of the "center" of a distribution of values. There are three major types of estimates of central tendency: mean, median, and mode.

\section{b. The dispersion}

It refers to the spread of the values around the central tendency. There are two common measures of dispersion: range and standard 


\section{deviation.}

\section{Correlation}

Pearson Product Moment correlation is to look for direction and strength of the relationship between independent variable (X) and dependent variable (Y) and the data will be in interval and ratio.

The strength of the relationship is shown by the correlation coefficien value (r), between

-1 and 1. The direction of the relationship is stated in the form of positive (+) and negative (-).

When $\mathrm{r}$ is equal to -1 , it shows the perfect negative relationship, meaning that the opposite relationship occurs between the variable $X$ and the variable $\mathrm{Y}$. When the variable $\mathrm{X}$ goes up, then the variable $\mathrm{Y}$ is down. On the contrary, when $r$ is equal to 1 , it shows perfect positive relationship which means the relationships between the variable $X$ and the variable $\mathrm{Y}$ is in line. When the variable $\mathrm{X}$ goes up, then the variable $\mathrm{Y}$ does too. The following table shows the level of correlation and the strength of the relationship (Siregar, 2013: 251-252):

Table 2. Level of Correlation and Strength

\begin{tabular}{ccc}
\hline $\mathbf{N}$ & $\begin{array}{c}\text { The Value } \\
\text { of } \mathbf{r}\end{array}$ & $\begin{array}{c}\text { The Strength of } \\
\text { Relationship }\end{array}$ \\
\hline $\mathbf{0}$ & $0,00-0,199$ & None or very weak \\
\hline $\mathbf{2}$ & $0,20-0,399$ & Weak \\
$\mathbf{3}$ & $0,40-0,599$ & Moderate \\
$\mathbf{4}$ & $0,60-0,799$ & Strong \\
\hline $\mathbf{5}$ & $\mathbf{0 , 8 0 - 1 , 0 0 0}$ & Very strong \\
\hline
\end{tabular}

\section{Simple Regression}

The simple regression is used to explain the relationship between one dependent variable and one independent variable. It will show the strength of relationship of the variable $\mathrm{X} 1$ to the variable $\mathrm{Y}$ and the variable $\mathrm{X} 2$ to the variable $\mathrm{Y}$. The variable $\mathrm{X} 1$ has not affected the variable $\mathrm{Y}$, when the relationship value of $\mathrm{X} 1$ against $\mathrm{Y}$ is zero. The variable $\mathrm{X} 1$ has affected the variables $\mathrm{Y}$, when the relationship value of $\mathrm{X} 1$ against $\mathrm{Y}$ is not equal to zero.

The relationship value of $\mathrm{Y}$ against $\mathrm{X} 1$ is shown by the notation $\square$ in the regression equation:

$$
\square=\square 0+\square 1 \square 1+\square
$$

Where

: is the value of the dependent variable,

what is being predicted or explained

$\square 1$ : first independent variable that is explaining the variance in $\mathrm{Y}$ (principal leadership) 


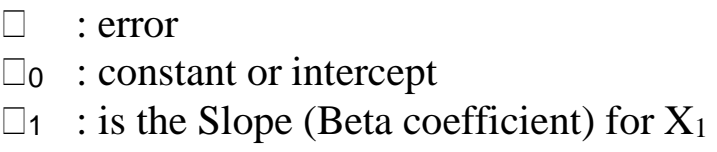

To test whether X1 affects $\mathrm{Y}$ or not, we use the t-test. If the $\mathrm{t}_{\text {count }}$ is bigger than $t_{\text {table }}$ with sig-value/prob .05, it means $\mathrm{X} 1$ has affected $\mathrm{Y}$. To measure the capabilities of the X1 determines the variation of $\mathrm{Y}$, the coefficient of determination ( $\mathrm{R}$ squared) is used.

Based on the above discussion of the principal leadership, the school climate and the teachers' job satisfaction, the operational hypothese of this research were formulated as follows:

1. There is a positive correlation between the principal leadership and the teachers' job satisfaction, meaning, the higher the school leadership is, the higher the teachers' job satisfaction will be.

2. There is a positive correlation betweeen organization climate and teachers' job satisfaction, meaning, the higher the school leadership is, the higher the teachers' job satisfaction will be.

The statistical hyphoteses were formulated as follows:

$$
\begin{aligned}
& H_{0}: \square 1=0 \\
& H_{1}: \square_{1} \neq 0
\end{aligned}
$$

The meaning of the above hypotheses is that the null hypotheses will be rejected if the Beta coefficient for X1 is not equal to zero.

\section{Multiple Regression}

Multiple regression analysis is used for finding out the degree or strength of a relationship between three or more variables as well as the contributions that is given simultaneously by variables $X 1$ and $X 2$ to the variable $\mathrm{Y}$ and also the partial contribution provided by the variables $\mathrm{X} 1$ againts $Y$ and $X 2$ against Y. (Siregar, 2013:262)

To test whether $\mathrm{X} 1$ and $\mathrm{X} 2$ affects $\mathrm{Y}$ or not, we use the $\mathrm{F}_{\text {count. If the }} \mathrm{F}_{\text {count }}$ is bigger $\mathrm{F}_{\text {table }}$ with sig-value/prob .05, it means $\mathrm{X} 1$ and $\mathrm{X} 2$ has affected $\mathrm{Y}$. To measure the capabilities of $\mathrm{X} 1$ and $\mathrm{X} 2$ determines the variation of $\mathrm{Y}$, the coefficient of determination ( $\mathrm{R}$ squared) is used.

Then the operational hypothese is stated as, there is a positive correlation betweeen principal leadership and organization climate to teachers' job satisfaction, meaning, the higher the principal leadership and organization climate are, the higher the teachers' job satisfaction will be.

The statistical hyphoteses were formulated as follows:

$$
\begin{aligned}
& H_{0}: \square 12=0 \\
& \square 1: \square 12 \neq 0
\end{aligned}
$$

The meaning of the above hypotheses is that the null hypotheses will be rejected if the Beta coefficient for X1 and X2 is not equal to zero.

\section{RESULTS}


The data which were from 32 respondents with a total of 70 (the teachers' job satisfaction had 25 items, the principal leadership had 20 items, and the school climate had 25 items) were calculated. It was found 2 invalid items, meaning that they are dropped. Those are questions no. $1\left(\mathrm{r}_{\text {count }}=.333\right)$ for the teachers' job satisfaction instrument and question no. $17\left(r_{\text {count }}=.343\right)$ for the school climate.

An instrument is considered reliable if the value of $\alpha$ is at least .6 (Cohen, Manion and Marrison, 2007:506). The calculation was carried out by using SPSS program. After calculation by using Cronbach Alpha formula, the values of $\alpha$ were .873 for the teachers' job satisfaction, .961 for the principal leadership and .927 for the school climate. As all of values are higher than .6 , Then it can be concluded that all instruments are reliable, to be precised, two of them are highly reliable.

The results of $\mathrm{X}^{2}$ count were 9.42 for the teachers' job satisfaction, 2.88 for the principal

leadership and 6.10 for the school climate. With the degree of freedom (df) of each variable was the same that is 6 , and $X^{2}$ table with a $5 \%$ significant level (the chi-square table) was 11.07. Because all $\mathrm{X}^{2}$ count $<\mathrm{X}^{2}$ table, the distributions of all data were normal. It was obtained that the value of the probability (sig.) on Linearity of both were .000 . The value were less than adequate for the significant $(\alpha) 0.05$. Then it can be inferred that the relationship between the principal leadership (X1) and the teachers job satisfaction (Y) was linear. It was also linear for the relationship between the school climate (X2) and the teachers' job satisfaction (Y).

The descriptive statistics of $\mathrm{Y}$ is based on the

following table:

Table 3. Descriptive Statistics of the Teachers' Job Satisfaction

\begin{tabular}{llr}
\hline & \multicolumn{2}{c}{$\begin{array}{c}\text { Teachers' } \\
\text { Job } \\
\text { Satisfactio } \\
\mathrm{n}\end{array}$} \\
\hline $\mathrm{N}$ & Valid & 32 \\
& Missin & 0 \\
Mean & $\mathrm{g}$ & 4.1263 \\
Median & & 4.1250 \\
Mode & & $3.83^{\mathrm{a}}$ \\
Std. Deviation & & .37004 \\
Variance & & .137 \\
Range & 1.46 \\
Minimum & 3.38 \\
\hline Maximum & 4.83 \\
\hline Sum & 132.04 \\
\hline
\end{tabular}

Source: SPSS Data Computation

Based on table 3, we know that the mean is 4.12, the median is also 4.12 and the mode is 3.83. It means most teachers agreed that dimensions Y1-Y6 
have influenced their job satisfaction. The data shows minimum (3.38) and maximum (4.83) with sum (132.04) and standard deviation (.37), meaning that the data is closer to mean and is not really varied.

The description of variable $\mathrm{X} 1$ is as follows:

Table 4. Descriptive Statistics of the Principal Leadership

\begin{tabular}{lrr}
\hline & & $\begin{array}{r}\text { The Principal } \\
\text { Leadership }\end{array}$ \\
\hline $\mathrm{N}$ & Valid & 32 \\
Meassing & 0 \\
Median & 4.2984 \\
Mode & 4.3000 \\
Std. Deviation & 4.00 \\
Variance & .49064 \\
Range & .241 \\
Minimum & 2.00 \\
Maximum & 3.00 \\
\hline Sum & 5.00 \\
\hline
\end{tabular}

Source: SPSS Data Computation

Based on table 4, we know that the mean was 4.29 , the median was also 4.30 and the mode was

4.00. It means most teachers agreed that dimensions X1.1. - X1.3. had influenced their job satisfaction. The data showed minimum (3.00) and maximum (5.00) with sum (137.55) and standard deviation (.49), meaning that the data was closer to mean and was not really varied.

The last one is the $\mathrm{X} 2$ description based on the following data: Table 5 .

Descriptive Statistics of the School Climate

\begin{tabular}{|c|c|c|}
\hline & & School Climate \\
\hline \multirow{2}{*}{$\mathbf{N}$} & Valid & 32 \\
\hline & Missing & 0 \\
\hline Mean & & 4.1589 \\
\hline Median & & 4.0833 \\
\hline Mode & & 4 \\
\hline Std. Deviation & & 0.35441 \\
\hline Variance & & 0.126 \\
\hline Range & & 1.42 \\
\hline Minimum & & 3.54 \\
\hline Maximum & & 4.96 \\
\hline Sum & & 133.08 \\
\hline
\end{tabular}

Source: SPSS Data Computation

Based on table 5 , the mean was 4.15 , the median was also 4.00 and the mode 
was 4.00. It means most teachers agreed that dimensions X2.1 - X1.5 had influenced their job satisfaction. The data showed minimum (3.54) and maximum (4.96) with sum (133.08) and standard deviation (.35), meaning that the data is closer to mean and was not really varied.

There is a correlation between the school leadership and the teachers' job satisfaction, with the correlation coefficient $(r)=.890$. The $r_{\text {count }}(.890)$ is higher than $\mathrm{rtable}_{\text {ab }}(.349)$. The interpretation of the data is it has is very strong relationship as it is between $.80-1.00$. It is also positive relationship or in one direction, the higher the principal leadership, the higher the teachers' job satisfaction will be. On the contrary, the lower the principal leadership, the lower the teachers' job satisfaction will be. Based on the t-test, it was obtained that $t_{\text {count }}(5.974)>t_{\text {table }}$ (1.699) with $\mathrm{df}(29)$ and value of sig. $\alpha$ .05 (see table 4.15.). The probability value (sig.) is .000 with sig. value $\alpha=$ .05 . Based on that data, sig. $(.000)<\alpha_{(.05)}(.05)$. Accordingly, $\mathrm{H}_{0}$ is rejected, thus there is a significant relationship between the principal leadership and the teachers' job satisfaction.

Based on the data the dominant indicator for the the principal leadership in on relationship of the principals with the members of organization $(93 \%)$. The principals developed effective communication and treated teachers fairly. Those contributed to the teachers' job satisfaction.

Based on the data the dominant indicator for school climate in on supporting management style (92\%) and also sense of responsibility (99\%). The school climate developed effective communication and treated teachers fairly. Those contributed to the teachers' job satisfaction.

It is found that the relationship between the principal leadership and school climate to the teachers' job satisfaction (r) was .905 . It showed a very strong relationship that was between $.8-1.00$. The contribution simultant of the school leadership (X1) and the school climate (X2) to the teachers' job satisfaction $(\mathrm{Y})$ is $\mathrm{R}^{2} \mathrm{X} 100 \%=(.905)^{2} \mathrm{X} 100 \%=81.9 \%$. The rest $18.1 \%$ is related to other variables which are not mentioned in this research.

Another finding is that the principal leadership (X1) and the school climate (X2) with Y sig =

.000 for $\alpha=.05$. The value of sig $=.000<.05$, thus $\mathrm{H}_{0}$ was rejected and the conclusion is there is a relationship between the principal leadership and the school climate simultantly to the teachers' job satisfaction.

Multiple linear regression can be used to predict the teachers' job satisfaction which has a relationship with the principal leadership and school climate, by comparing the value of $\mathrm{F}_{\text {count }}$ with $\mathrm{F}_{\text {table }}$ and also comparing the value of probability (sig.) with $\alpha . F_{\text {count }}$ from table 4.14 is 65.728 and the probability (sig.) is .000 . Thus, $F_{\text {count }}=65.728>F_{\text {table }}(2,29)=3.327$ and the probability (sig.) $=.000<\alpha=.05$. The conclusion is the multiple linear regression can be used to predict the teachers' job satisfaction which is influenced by the principal leadership and school climate.

The multiple regression model to predict the teachers' job satisfaction was influence by the principal leadership and the school climate is:

$$
\square=.897+.534 \square 1+.223 \square 2
$$

The value of relationship between the principal leadership and the teachers' job satisfaction is .534 which means if the principal leadership would be 
increased 1 unit, the teachers' job satisfaction would increase .534 units of $53.4 \%$. The value of relationship between the school climate and the teachers' job satisfaction is .223 which means if the school climate would be increased 1 unit, the teachers' job satisfaction will increase .223 units of $22.3 \%$.

The hypothesis showed that the principal leadership (X1) and the school climate (X2) had a positive and significant relationship to the teachers' job satisfaction. The relationship is linear, that is a stright line. Furthermore both independent variables can explain the dependent variable with the value of sig. .000 which is less than $\alpha=.05$.

Based on the previous description, the hypotheses $\mathrm{H}_{0}$ was rejected, because the test has shown that there is a positive and significant relationship between the principals and the school climate simultantly to the teachers' job satisfaction. The higher the principal leadership and the school climate are, the higher the teachers' job satisfaction will be. The lower the principal leadership and the school climate are, the lower the teachers' job satisfaction will be.

\section{E. DISCUSSION, CONCLUSION, IMPLICATION AND RECOMMENDATION}

Based on the data analysis, it was found that for the teachers' job satisfaction variable, with the mean: 4.12 and mode: 3.83 , teachers look satisfied with their job. It can be caused by prominently indicator (Y5: 99\%) the opportunity to develop. Most of the teachers are still young and categories as Gen-Z. With all the characters of their generation, they want to work fast, effective and collaborative but still they are competitive. Opportunity to develop will be one thing they are looking for as they can get the training, knowledge and additional skill for free as the school will pay for them. As this is one of the interesting points for teachers to feel satisfied in their job, the school leaders needs to analyse further to get the suitable treatment for the teachers.

The data from principal leadership also showed that the teachers feel satisfied with their principals (mean 4.29, mode 4.00) especially for indicator X1. 3. (93\%), where the principals' relationship with teachers are felt supporting, communicative and have a fair treatment. Young teachers, who prefer to have leaders who are the combination of tranformational and interpersonal leadership will be satisfied to work with when they can express their opinions without strict seniority boundary.

In the discussion of school climate, the data gain showed that the teachers still feel satisfied with their job with the mean 4.15 and mode 4.00. The focus on sense of responsibility with the procentage $99 \%$. Related to the previous paragraphs, the young teachers are very active and they really want to get involved in other school activities, committee, and even for structural position. Accordingly, the sense of responsibility will be the advantage for school. The right treatment to those teachers will make the school can develop progressively.

After conducting the research, the researcher can now draw the following conclusion: 
The relationship between the principal leadership (X1) and the teachers' job satisfaction (Y) was shown by the result of Pearson product moment correlation coefficent $(r)=.890$. This means there was a very strong, positive and significant correlation between the principal leadership and the teachers' job satisfaction. Accordingly the hypothesis that said "There is a positive correlation between the principal leadership and the teachers' job satisfaction, meaning, the higher the principal leadership is, the higher the teachers' job satisfaction will be" was proved.

1. The relationship between the school climate (X2) and the teachers' job satisfaction (Y) was shown by the result of Pearson product moment correlation coefficent $(r)=.795$. This means there was a strong, positive and significant correlation between the school climate and the teachers' job satisfaction. Accordingly the hypothesis that said "There is a positive correlation between the school climate and the teachers' job satisfaction, meaning, the higher the school climate is, the higher the teachers' job satisfaction will be" was proved.

2. The relationship between the principal leadership (X1) and the school climate (X2) simultantly to the teachers' job satisfaction (Y) was shown by the result of regression correlation coefficent $(r)=$ .905. This means there was a very strong, positive and significant correlation between the principal leadership and the school climate and the teachers' job satisfaction. Accordingly the hypothesis that said "There is a positive correlation between the principal leadership and the

school climate to the teachers' job satisfaction, meaning, the higher the principal leadership and school climate are, the higher the teachers' job satisfaction will be" was proved.

The implications of this research are:

1. The effort to increase the teachers' job satisfaction can be done if the management realized that teachers are assets. They need to be maintained in many ways. A study by Sonmezer and Eryaman (2008: 189-212) theoretically stated that dissatisfied employees may reduce their levels of performance and efficiency and may sabotage the work or leave the job. Dissatisfied teachers will be more like burdens when they prefer to stay without giving positive influence. Accordingly, a deeper thought must be done by the school leaders together with the management, starting from the recruitment process until they are retired, there must a consideration about teachers' job satisfaction.

2. The principal leadership is always be the one that is behind the teachers. Just supporting them right now is not enough. As stated in this research result, they really want principals who have a future view and can communicate effectively. Another implication that is usually expected is being friendly. Most of teachers in this SPK school are still young (25-35), there are the millennials.

They like to deal with technology, work collaboratively, hang around, innovative and competitive. The consequence to recruit 
these potential young people in the school must be realized by the principals. Otherwise, the school will be a stepping stone for their next journey.

3. The principals are often Baby Boomers or Generation Xers, meanwhile there are increasing Millennials who now become teachers. Focusing on their job performance and satisfaction will be the next task of the school leaders. Davin Thompson and Rice (2017: 2) stated that millennials are generally not hesitant to change where they work, and considering the acute teacher shortages nationally in many schools, it is important to help millennial teachers be effective, happy, and satisfied at work. Providing the suitable school climate as stated in the result of the research, will be one task that need to be reconsidered both by the school leaders and management.

Finally, the recommendations are presented, as follows:

1. The principals as the ones who set the goals and target and direct the teachers to achieve them, should know how to energize the teachers. As the school has more young millenial generations, they must be able to hold them by keeping them stay in the institution. As we know most of them are potentials and with their gen-Y characters, they tend to move from one place to another. How to keep them stay will be another homework for the leaders and as for management on how to facilitate them to keep their job satisfaction high.

2. The school climate is one variable that can influence teachers' job satisfaction. The newest trend in SPK schools is creativity learning which make them feel free to learn and to express themselves when teaching. The opportunity to develop and being creative is not always in there. Strict regulations and policy in school must be reconsidered to support the dynamic condition. Creating a more relaxed atmosphere will support the performance of the teachers so that they will have the satisfaction of their own works. Training must be provided to make them develop regularly. That will make their skills improve to catch up the education progres.

3. Support facilities provided by the school can increase the teachers' job satisfaction. In addition they can also be more productive without any obstacles when working. For example, the availibity of a computer or laptop, it is best not to give teachers a reason they can not work because their computers were not suitable for working.

\section{REFERENCES}

Bartz, David, Tompson, Kyle and Rice, Patrick. (2017). Enhancing the Effectiveness of Millenial Teachers through Principals using Performance Management: National Forum of Educational, Administratin and Supervision Journal, 35 (4)

Beare, H., Caldwell, B., and Millikan, R. (1992), Creating an Excellent School. London: Routledge. Cuban, L. (1988). The Managerial Imperative and the 
Practice of Leadership in Schools. Albany, NY,

State University of New York Press.

Davis, James H. (2001). Building Organization Commitment to Reengineering Initiatives: Theory on Organization Mobilization. (http://acenet.edu/ca;ec/dost/;earmomg/dl.org.commitment.html)

Dimmock, C. and Walker, A. (2002). School leadership in context - societal and organisational cultures, in Bush, T. and Bell, L. (Eds), The Principles and Practice of Educational Management, London, Paul Chapman.

Fred, Luthans. (2008). Organizational Behavior. New York: Mc.Graw-Hill Company, Inc.

Halpin and Croft .A.W and Croft D.B. (1963). The Organizational climate of the schools. Chicago: Mid-West Administrative center.

Hinic, Darko and Grubor Jelena and Brulic, Lida. (2017). Followership Style and Job Satisfaction in Secondary School Teachers in Serbia. SAGE Educational Management Administration \& Leadership. Vol.45(3), published May 2017.

Ivancevich, Gibson and Konopaske, Donnelly. (2006). Organizations Behavior, Structure, Process.

New York: Mc.Graw-Hill Company, Inc.

Leithwood, K., Jantzi, D. and Steinbach, R. (1999). Changing Leadership for Changing Times.

Buckingham: Open University Press.

Mullins, Laurie J. (2005). Management and Organisational Behavior. England: Financial Times) Robinson, V. (2007). 'The impact of leadership on student outcomes: Making sense of the evidence'

Research Conference Paper. The Leadership Challenge: Improving Learning in Schools. Australian Council for Educational Research.

Robbins, Stephen P. (1996). Organizational Behavior. New York: Prentice-Hall International

Sirota, David., Mischkind, Louis A and Meltzer, Michael Irwin. (2005). The Enthusiastic Employee.

New Jersey: Wharton School Publishing

Sonmezer, M.G. and Eryaman, M.Y. (2008). A Comparative Analysis of Job Satisfaction Level of Public School: Journal of Theory and Practice in Education, 4 (2).

Spector PE. (1997). Job Satisfaction: Application, Assessment, Causes and Consequences. Thousand Oaks, CA: SAGE

Spector, P.E. (2008). Industrial and organizational behaviour. (5th Edition). New York: John Wiley \& Sons, Inc.

Stoll, L. and Fink, D. (1996), Changing our Schools. Milton Keynes: Open University Press

Tagiuri, R. and Litwin, G.H. (1968). Organizational Climate: Exploration of a concept Boston: Harvard University.

Tang, Leong Weng and Chiu, Lim Khong. (2002). Iklim Kerja dan Kejenuhan di Kalangan Guru. (http://members.tripod.com/ipdares/bumt/html)

Vedavathi, B. (2017). A Study of Secondary School Organization Climate and Work Values of Secondary School Heads. IOSR Journal of Research and Method in Education. Vol 7 (2).

Wirawan. (2014). Kepemimpinan: Teori, Psikologi, Perilaku Organisasi, 
The Relationship Between Principal Leadership And School Climate And Teachers' Jo6 Satisfaction OfThe SFK Secondary School In Pamulang, Tangerang Selatan

Aplikasi dan Penelitian. Jakarta: Rajawali Pers. 

